\title{
Habitus Creativity of Elementary Teacher Education Department Students in Creating "Batik Cap"
}

\section{Probosiwi}

Campus 5 of Universitas Ahmad Dahlan Yogyakarta

Jl. Ki Ageng Pemanahan Number 19, Sorosutan, Umbulharjo, Yogyakarta 55162

E-mail: probosiwi@pgsd.uad.ac.id

\begin{abstract}
The purposes of this research are finding out the behaviour and creativity patterns of students in making "batik cap". Subjects of this research were students of the Primary School Teacher Education Department at Universitas Ahmad Dahlan Yogyakarta who took the Art and Skills Education course in the even semester of the Academic Year 2018/2019. The stages of the process analyzed include making batik designs, creating "batik cap" masters, "batik cap" artworks, and finishing the artworks. The research method is qualitative research. Data collection techniques are done by interview, observation, and document review. The data analysis technique used is narration. The results showed that $4 \mathrm{P}$ concept contains habitus as a system of practical production schemes, systems of perception, and appreciation practically related to aesthetics that allow for non-aesthetic responses within an object, differently defined in terms of philosophical logic. Students did the practices they had followed the procedure of creative thinking quite well.
\end{abstract}

Keywords: habitus, creativity, "batik cap"

\section{ABSTRAK}

Tujuan dari penelitian ini adalah untuk mengetahui pola perilaku dan kreativitas siswa dalam pembuatan "batik cap". Subjek penelitian ini adalah mahasiswa Program Studi Pendidikan Guru Sekolah Dasar di Universitas Ahmad Dahlan Yogyakarta yang mengambil mata kuliah Pendidikan Seni dan Keterampilan pada Semester Genap Tahun Akademik 2018/2019. Tahapan proses yang dianalisis meliputi pembuatan desain, master "batik cap", karya seni "batik cap", dan menyelesaikan karya seni. Metode penelitian adalah kualitatif. Teknik pengumpulan data dilakukan dengan wawancara, observasi, dan tinjauan dokumen. Teknik analisis data yang digunakan adalah narasi. Hasil penelitian menunjukkan bahwa konsep $4 P$ berisi habitus sebagai sistem skema produksi praktis, sistem persepsi, dan penghargaan yang secara praktis terkait dengan estetika yang memungkinkan respons non-estetika dalam suatu objek, berbeda didefinisikan dalam hal logika filosofis. Mahasiswa melakukan praktik cukup baik dengan mengikuti prosedur berpikir kreatif.

Kata Kunci: habitus, kreatif, "batik cap" 


\section{INTRODUCTION}

Indonesia has many cultural artifacts which spread over several islands like traditional dance, regional weapons, language, custom clothes, culinary, tourism, and crafts. Craft items include materials from wood, leaf, fabric, stone, clay, roots, fiberglass and so on. In this paper, the author took one of the item of crafts that is fabric called "batik". One of the very famous and important textile products from Indonesia is "batik". "Batik" was made by people in Java, as one of the traditions and cultural heritage in Indonesia. "Batik" has a very long historical path. The word batik comes from the Javanese language, "mbatik" ("mbat" and "tik"), the word "mbat" is also known as "ngembat" which means the word is lifted or discarded and the meaning of the word "tick" is a dot. So, based on the meaning of two words, the meaning of batik is to throw a point several times on the fabric. Batik is produced by dipping fabric into a dye solution (Susanty, 2015). Dots were obtained from hot wax drops on the fabric surface. The hot wax is solid "malam" which dissolves in the pan using hot coals. During the "malam" dissolving on the coal fire, it must remain lit and the craftsman must be careful in dropping it from the hand.

"Batik" is one of the Indonesian nation's wealth. "Batik" is a piece of cloth applied by means of a dye-resist technique using "batik-wax" as the resisting medium. Indonesian batik process has designated by UNESCO as a Masterpiece of Oral and Intangible Heritage of Humanity. As part of the acknowledgment, UNESCO insisted that Indonesia has been preserved their heritage. This fact should be grateful and responded with efforts to develop and preserve Indonesian batik. One effort to develop and preserve Indonesian batik is to adopt green energy technologies in the production process (Syahputra, 2017).

"Batik" is one of the creative industries that have potential as part of a city branding. "Batik" industry can also be categorized as highly creative one because it is processed and developed by artistic ideas through a variety of distinctive and original motif. So, "batik" is able to contribute significantly to the income of the nation, known also as a creative economy. Furthermore, "batik" is an eco-art industry which puts the concept of environmentally friendly industries (Widiaty, 2015).

According to those descriptions, "batik" learning for elementary students did not have been taught. There are many function "batik" for industry and mass product. Based on Core Competencies (KI) and Basic Competencies (KD) for elementary students on Grade 5 wrote 3.4 understanding regional art and 4.4 making regional art, making "batik" is one of the alternative options to representation both. Because "batik" is one of the cultural richness in Indonesia, so students must been known and participate to preserving. The ways to help it can do "batik" learning in course. For strengthen the author argument, Hestiasari Rante wrote, "batik" as one of Indonesian cultural heritage is brought into this study and 
is introduced to children in a different platform (Rante, 2014). Mastery of material about "batik" needs to be done by students. This is supporting their basic understanding of "batik", so they have a lot of information and apply to make "batik" with certain techniques. Besides the technique, students need insight into the basic elements of visual arts as a method of compiling motifs and visualizing "batik".

Visual arts students learn to generate a meaningful and aesthetic symbol for an evident topic by using such design elements and principles as color, line, form, shape, space, texture, balance, proportion, perspective, movement, pattern, emphasis, repetition, rhythm, variety, harmony, and unity (Ulger, 2018). The style of "batik" is dominated by the fine art elements in the form of lines and dots have found in motifs such as Kawung, Banji, Parang, Ceplok, Lurik, and others. Aesthetic symbol like line, dot, color were contained in "batik" motifs and there are combining with composition, balancing, repetition, and so on. So, the craftsman was considered pattern of "batik" according to the aesthetic symbols. In addition the various of "batik" motifs also have a type classification including "batik tulis", "batik jumputan", "batik cap" and so on. There was explained by Wulandari in her book entitled Batik Nusantara: Makna Filosofis, Cara Pembuatan \& Industri Batik that kind of "Batik" in Indonesia has various types that are influenced by classical to modern and hereditary traditions, namely since the Majapahit Kingdom. In addition, the types of "batik" are also caused by the interaction of the Indonesian people with foreign nations, both in fraternal relations, international marriage, trade, diplomatic relations, and colonialism by Western nations. The types of "batik" referred to include Chinatown "batik", Dutch "batik", Javanese Hokokai "batik", Rifa'iyah "batik", Keraton "batik", Sudagaran "batik", "Jawa Baru batik", Jlamprang, Terang Bulan, "Cap Kombinasi Tuli”, "Tiga Negeri Pekalongan”, Sogan Pekalongan, Tribusana, Pangan/ "Batik Petani", Coletan, Kemodelan, Osdekan, Modern, Contemporer, "Batik Cap", "Batik Tulis", and "Batik Tulis" (Wulandari, 211:84-101). The author focused on one of the type of "batik" is "batik cap" because it was learned to the subjects of this research.

"Batik cap" is a type of batik that is produced by being stamped on the surface of a cloth with certain motifs made of energy or wood. This type of batik is made by dipping or stamped first into a hot night and then pressed on the fabric surface. This process is carried out continuously so that a series of batik patterns or patterns will be formed on one sheet of cloth (Supriono, 2016:145). From another article said "batik cap" is a technique of wax-resist dyeing applied to a cloth made by printing the fabric with a copper stamp called a "cap" acting as mold (Sutari, 2015). Although "batik cap" was made with stamp tools but it also using wax-resist to reveals small parts. This technique usually calls "canthing" was used hot wax 
and pan did by the craftsman. "Batik cap" can defined as "batik" stamp tools because making process need "cap" master which made from copper.

Anugraha writes that "batik" stamp is one batik type that is produced by using specific stamp tool. One process need to be improved in "batik" stamp production process was the making of stamp tool. During the making of stamp tool, there is a process called scraping in which the surface of stamp tool is trimmed (Anugraha, 2015). About in the 1920s, we know another type, which is "batik cap". This type is a response to consumer demand for "batik" in a mass production. In this context, "batik" was begun to be industrialized (Widiaty, 2015). "Batik cap" become economic income which has selling opportunity faster because the amount of production that can be made in large quantities in just one time. Production cost can be minimalized but the quantity get lots.

While the "canting" has been a part of the hand-drawn batik process for centuries, the "cap" is considered a "modern" development. Based on ancient wood blocks, the copper "cap" came into use around 1850. By stamping the cloth with the "cap", thus creating the intricately detailed "batik" motifs immediately, a cloth which might take three months to "batik" with the canting could be finished in a day (Kaun, 2001). Based on the estimate time making "batik tulis" which using relatively long time, then learning "batik" can be done making alternative "batik cap" using simpler materials. The stamp materials can get by students easily like from paper (Malaga/ Duplek or food box wrapped paper).

The mastery of knowledge of making "batik" can be seen from the ability of students to master knowledge related to the understanding "batik", the knowledge of tools and materials used in making "batik", the types of "batik" motifs, and the steps of making "batik". After learning about making "batik", it is expected to have knowledge about making "batik". Mastery of knowledge in making "batik" is very important, because it can form mutual tolerance with each other and improve the skills of students in the process of making "batik". (Sovia: 2016) The author who is a lecture in the class of Elementary Teacher Education Department was invited students making "batik cap" that starting with drawing up a design motif, stamps master, stamping a stamp master on the fabric. For getting good artworks, students need creativity.

Creativity is the ability to think of things in new and unusual ways and give birth to a unique solution to the problems faced. Creativity is a way of thinking and acting or creating something original and valuable / useful for that person and others. In line with what was stated by Gallagher revealed that creativity is related to the ability to create, create, discover a new form and or to produce something through imaginative skills, this means that creativity is related to the experience of expressing and actualizing individual identities in the form integrated in relationships with oneself, with nature and others (Sit, 2016:1). Creativity seems to 
originate from a transformation of different thought processes, intuitive, and logical reasoning (Savoie, 2015).

Creative thinking is seen as being critical in facing various challenges in people's lives. Educators and policymakers around the world have called for more opportunities in the classroom for students to develop their creative abilities for example, Asian education reform has recently "incorporated" creative elements into regular classrooms, resulting in improvements in attitudes, conceptions, abilities, and student behavior in creative development. The big picture in creativity consists of 4P (people, processes, products and press), or it can be said that creativity is formed due to environmental influences (Daly: 2016).

Learning about the "creative process" helps students when they carry out creativity activities with discipline. Instructions on how to make a work or an object enable them to be involved in various pedagogical approaches in all disciplines. The results of this analysis document the quality of the learning experience in university classrooms during the teaching of the creative process. Suggested pedagogical improvements include building a repertoire of successful works in a field, and self-reflection about the creative process (Daly, 2016). The description of the results of this study has continuity with the practice of making "batik cap" for Elementary Teacher Education Department's students which focuses on effective and efficient learning experiences. Creative steps certainly become their foundation in the process of making "batik cap". All steps will be done of students need method to reveals their creativity.

Learning interactive methods is a non-traditional approach as a new form of creative teaching, where young people are simultaneously involved to feel and understand the original and the concepts of core content areas in education such as science, technology, and mathematics from outside perspective. This article is an attempt to answer questions about how to keep children able to live life creatively. The analysis focuses on fine arts and their interrelationships with interactivity and creativity, and art exploration shapes new ways for children to improve their practices and interactions in the environment. In the aspect of fine arts, the nontraditional approach is found in their creative process in creating skill-based artwork by solving problems encountered both in terms of tools and materials (Stavridi, 2015). The description of this research has relevance to the research conducted by the author, because Elementary Teacher Education Department's students have a tendency to imitate or adapt existing work, because the learning styles of elementary school students are more striking with the presence of more concrete objects. So, creativity on making "batik cap" is basic analyze for looking at student habitus.

Michael Grenfell and Cheryl Hardy (2007:28) write that the basic concept of Pierre Bourdieu's thinking lies in habitus and arena. Both are interpreted as 
subjective and objective dimensions of scientific epistemology. Understanding and use is developing in various works and studies of practical contexts. Bourdieu used habitus in his earliest research, in his analysis of bachelor farmers in Béarn to describe aspects of their physical appearance and their speech characteristics. More formally he defined it as habitus is a system of practice production schemes and practical systems of perception and appreciation.

Bourdieu further emphasizes his opinion related to aesthetics that allows the existence of non-aesthetic responses within an object, different as defined in terms of philosophical logic (Grenfell \& Hardy:41). Furthermore, Bourdieu defines habitus as a set of social agents (individuals, groups, or agencies) consisting of things that are structured and regulate an order. Things that have been structured in the past and the structure that exists in the present, such as the experience of family care and education and educational experience (Grenfell, 2008:51).

Habitus conceptualizes the relationship between purpose and subjectivity or "outside" and "inside" by describing how these social facts become internalized. Bourdieu states that habitus is "socialized subjectivity" and "social form". In other words, the structure that is internalized, the purpose is made subjective. This is also how the person comes to play a role in the social-disposition that underlies our actions which in turn contributes to the social structure. Habitus thus unites the objective social structure and subjective personal experience: "dialectic internalizing externalities and externalizing if internalities" (Grenfell, 2008: 52).

The author took one of the agents of groups because students divided their class into group. Each group is consists in 4-5 persons and ready for doing practice on outing class. The experience of family care and education and educational experience of this course be seen from activities when they are preparing the practice. The activities of habitus are including "socialized subjectivity" and "social form" meant where their come from and characteristic roles. The author using 4P concepts to look how the students do in their habitus creativity for making "batik cap". Learning model is used by art-based learning. Johan's (2018) explains that the implementation of art education in elementary schools must consider that art education as a means for educative play and build creativity. If we use the art of education as a means of education, the approach must be in accordance with the purpose of art creation. Expected competence of art education for elementary school children is.

1. Being able to integrate the elements of ethics, logic and aesthetics, including: knowledge, understanding, perception, analysis, evaluation, appreciation, and production through visual language, voice, motion, and roles.

2. Having sensory sensitivity, aesthetics and artistic feelings through exploratory experiences, expressing and creating in the cross field in 
emotional, intellectual, moral, spiritual and intelligence difficulties according to the needs and development of children.

3. Able to be creative in visual language, voice, motion and role in developing the ability of perception, understanding, appreciation, creativity in production.

4. Having basic skills and being able to create based on inspiration that comes from nature and the environment around children in processing the art medium.

5. Able to appreciate their own work and the work of others and the diversity of local cultural arts and islands.

6. Able to play, present artwork and/ or design, display it in class and or in the school environment.

The objectives of competency-based arts education are alternatives to: (1) bring art education and the world of art closer; (2) guaranteeing the general basis of art education; (3) focus on results and processes at the same time; (4) introducing flexible learning; (5) acknowledging previous learning; and (6) guarantee multiple entries and exits. Thus art education in schools which include art, music, dance and drama, can be used as a basis for education in shaping the soul and personality (moral character). Art education can be used as a basis for education, because to form a good personality is done through art education.

Reingold (2018), five reasons why art learning arises based on students' responses to questions about whether they enjoy learning through art and what they feel is offered by art, including.

a. Learning through art provides an opportunity to express creativity.

b. Learning through art leads to better remembering texts.

c. Learning through art provides an opportunity to feel successful.

d. Learning through art leads to collaboration which results in deeper thinking about material.

e. Learning through art provides opportunities to be challenged in new ways. Art-based research as a set of methodological tools used by qualitative researchers as a tool adapts the principles of creative arts to answer social research questions holistically and the ways involved in which theory and practice are interrelated. The author deciding for choose Reingold concepts are learning art provides an opportunity to express creativity, art leads to better remembering texts, art provides an opportunity to feel successful, art leads to collaboration which results in deeper thinking about material, art provides opportunities to be challenged in new ways. Art-based learning concepts from Reingold analyzed from affective, cognitive, and psychomotor aspects. 


\section{MATERIALS AND METHOD}

Qualitative research applied to natural background or in the context of a need (entity), because of natural ontology calls for the facts as a whole that can't be understood if separated from its context (Moleong, 2018:8). Furthermore Moleong (2018:9), explained that qualitative research uses interviews, observations, and document review methods. This research has several considerations, namely the adjustment is easier if faced with plural facts; presents the nature of the relationship between researchers and respondents directly; qualitative methods are more sensitive and more adaptable to the many sharpening of the mutual influence on the patterns of values encountered.

Interviews are one of the most widely used research data collection tools that enable researchers to collect data from respondents in a variety of situations and contexts (Sarosa, 2017:47). Types of interviews in qualitative research consist of three types, namely structured interviews, unstructured interviews, and semistructured interviews. In this study, the author uses the type of unstructured interview, which is informal, there are no guidelines whatsoever, starting with exploring a general topic together with participants (Sarosa, 2017:49).

Observation is carried out by means of field studies that are observations of humans in their "habitat", where the authors try to find the original "habitat" of the participants. Field studies are not limited by specific places and times such as interviews, interaction between researchers and participants only lasts for a longer time, nuanced informal, researchers can explore and find information that is not revealed, researchers can observe what actually happened. Types of observations in qualitative research are divided into two, namely observation and participatory observation. Observations are researchers observing participants as outsiders, researchers can be present in the daily lives of the participants but do not take any role in their activities. While participatory observation is an activity carried out by researchers who participate in the daily activities of the participants (Sarosa, 2017: 60-61).

The process of carrying out field studies is carried out in three stages, such as planning (deciding what to do, reasons for conducting research, resource requirements), collecting data (gathering information, making notes, and observing), and analysis (analyzing the data that has been collected and then writing the report) (Sarosa, 2017: 64-65). The reasons for observation techniques used in qualitative research are as follows (1) observation techniques are based on direct experience, if the data obtained is not satisfactory, researchers will usually ask the research subjects; (2) observation techniques are possible to see and observe themselves and then record the behavior and events as they occur in the actual situation; (3) observation allows researchers to record events in situations relating to propositional knowledge and knowledge obtained directly from data; (4) doubts 
often occur to researchers, so the best way is to check the confidence of the data by utilizing observations; (5) the technique enables researchers to be able to understand complex situations and complex behaviors; (6) observations are made if in certain cases communication techniques are not possible to use (Moleong, 2018: 174-175).

Document review is done by viewing, reading, and reviewing documents that are considered relevant for research. Sarosa (2017: 65), writes that documents are all material things in written form made by humans, all records both in paper (hardcopy) and electronic (softcopy) such as books, mass media articles, diaries, manifestos, laws, minutes, blogs, pages web, photos, and so on. Moleong (2017: 208) explains that field notes have an important role in qualitative research because the discovery of knowledge or theory must be supported by concrete data and not supported by those from memory. The form of field notes consists of the front page and subsequent pages accompanied by paragraph instructions and margins. This research field note was written by the author in a small notebook that contains when, where, who was observed in certain aspects. The contents of the field notes on qualitative research consist of descriptive and reflective sections. Descriptive part is the longest part of all events and experiences that are heard, seen, and recorded as completely and objectively as possible. This section contains the subject's selfdescription, dialogue reconstruction, dialogue reconstruction, notes on special events, observer behavior (Moleong, 2018: 211-212). Whereas the reflective part has a special place to describe something related to the observer itself which includes speculation, feelings, problems, ideas, something that directs, impressions, and prejudices (Moleong, 2018: 212).

Based on the description, the interview process was conducted with the intended participants were even semester (4 and 6) Elementary School Teacher Education Department students who were studying Visual Arts and Skills Education course in academic year 2018/2019. Observation is aimed from the fifth to the seventh meeting on the course. In the fifth meeting, students were given material about printed batik, printed batik tools, printed batik making techniques. At the stage of making batik, students are asked to form groups of 4-5 people in each groups, they negotiate to determine what batik motifs will be made later. Each group is required to make a printed batik design on A4 paper sheets measuring 20 x $20 \mathrm{~cm}$ in color. Each group is also directed to routinely carry out consultations and design guidance at least twice to the supporting lecturer. After the design was revised and received approval from the professors, they then made a master or prototype of a batik stamp tool made from Malaga/ Duplek paper and boards hardboard cut. Each group is required to make a minimum of three master stamp motifs so that their batik is more varied. After the master stamp was made, each group practiced making printed batik with the coloring of naptol and indigosol in 
accordance with the existing design. The document review is done on photos of printed batik designs, the manufacturing process, and printed batik fabrics.

Data analysis techniques that can be used in qualitative research include coding, hermeneutics, semiotics, narratives. The author chooses narrative techniques, which are writings that contain a series of events from time to time outlined in sequence starting from the beginning, middle, and end. Narration is a story that contains empirical material collected by researchers. The material in question is the result of interviews with participants or personal narratives. Some approaches to narrative data analysis techniques are as follows (1) Reading or writing, from above or from below, realist, constructivist, critical, genre, sound, ante-narrative, deconstruction, grand-narrative, microstoria, story network, intextuality, causality, plot analysis, and theme analysis. The writer chooses the narrative technique approach to reading or writing. According to Sarosa (2017: 93), writing in narrative analysis as a tool for organizing and presenting research data in a logical, structured, and systematic manner, while reading in narrative analysis is interpreting the meaning of data in the form of narrative.

\section{RESULTS}

Based on $\mathrm{KI} / \mathrm{KD}$ grade 5 elementary school namely on the basic competencies points 3.3 and 3.4 containing understanding and making local art works, Elementary Teacher Education students have gone through a series of stages in making batik stamp in groups. Learning aspects achieved include affective, cognitive, and psychomotor.

1) In the affective stage, students are given material about printed batik, ranging from definition, insight, knowledge, dissemination, how to make printed batik. In the learning process students form groups of 4-5 people, so that the total number of groups in one class reaches 12 groups. The learning method at this stage uses the discussion method and the learning model used is Art-based Learning. The discussion was held after the students obtained material on the topic of developing batik cap. The results of the discussion showed that each group had an effort to develop motives that were integrated with their respective regions of origin. The average student seeks visual inspiration from the internet, they develop a framework for developing motifs. Next, students discuss how to construct a stamp tool from the material agreed upon in the class, namely natural materials. They use waste, rubbish, or used goods as an alternative to making stamp equipment. Development orientation is aimed at primary school students in the upper class, namely 5 th grade elementary school in accordance with applicable $\mathrm{KI} / \mathrm{KD}$. The output of the discussion process is the printed batik pattern framework that is worked on in two-dimensional fields. 
2) In the cognitive stage, students interpret the material by describing the concepts and steps of making printed batik and printed batik tools. Students use their basic knowledge of printed batik for elementary school children to compile reports in the form of written descriptions. Students use basic knowledge as a basis for integrating the actual stamp technique (with metal) into a process that is adjusted to the competencies of elementary school students.

3) In the psychomotor stage, students create intact batik designs on A4 HVS paper in a square area measuring $20 \times 20 \mathrm{~cm}$. Furthermore, students apply directly the stamp tool that has been made from natural materials on the Mori cloth in accordance with the batik designs that have been made and are colored. At this stage students also do the process of mixing colors from synthetic materials (naptol and indigosol) in the prepared container. The stamp is dipped in the dye container and directly applied to the fabric. To cope with small motifs, the students use a watercolor brush numbered 1, 2, 3 as a dab technique (painting) with a bunch of additional technique blocking and filling isen-isen. In the stage of the finishing work, students immersed batik cloth that had been stamped with fixanol liquid for 6 hours and the cloth that had been dried was trimmed by made the wolsom the edges of the fabric.

\section{DISCUSSION}

Based on the three aspects of learning that have been described, the big picture in creativity consists of $4 \mathrm{P}$, namely person, process, product, and press, the following description is obtained.

Table 1. Creativity Analysis of Elementary Teacher Education Students in Making "Batik Cap"

\begin{tabular}{|c|c|c|c|}
\hline No. & Aspect & Description Aspect & Remarks \\
\hline 1. & Person & $\begin{array}{l}\text { Is an individual who is in a } \\
\text { group per class that is } 4-5 \\
\text { people in a group. }\end{array}$ & $\begin{array}{l}\text { Each group of personnel } \\
\text { works together in making } \\
\text { the design framework for } \\
\text { motifs, batik pattern } \\
\text { designs, and stamped batik } \\
\text { works. }\end{array}$ \\
\hline 2. & Process & $\begin{array}{l}\text { The stages of making batik } \\
\text { work are done using a method } \\
\text { based on consultation and } \\
\text { guidance in the field. }\end{array}$ & $\begin{array}{l}\text { Preparation phase: } \\
\text { a. Each group conducts } \\
\text { consultation and } \\
\text { guidance in developing } \\
\text { a practice framework } \\
\text { and design motifs. } \\
\text { b. Each group consulted } \\
\text { and guided the design }\end{array}$ \\
\hline
\end{tabular}


of the printed batik patterns.

c. Each group consulted and guided the manufacture of batik stamp tools from natural materials by bringing pieces of motifs to be used.

d. Each group conducted a consultation and color guidance that was used for the design of printed batik (at least 3 types of colors).

e. Each group practiced batik making by bringing a set of tools in the form of a basin, a banner, a stove, a raffia rope, used plastic, clothes pins, gloves.

\section{Stage of manufacture:}

a. Step 1: wash the cloth a day before doing practice making "batik cap" with detergent and dry in the sun to dry.

b. Step 2: students heat the water to boiling.

c. Step 3: students dissolve naptol with hot water (basin 1) and color salt with cold water (basin 2).

d. Step 4: students dip the "mori" cloth to the basic color of the cloth in basin 1 then into basin 2 until it reaches the desired color density then dried in the sun to dry.

e. Step 5: dissolve the color of the second 
Probosiwi, Habitus Creativity of Elementary Teacher ...

naptol in the basin and dip the stamp tool until the surface is flat and flap it twice then apply it to the fabric following the finished design.

f. Step 6: dissolve indigosol coloring with warm water mixed with enough nitrite, then rub it on the surface of the fabric to add small motives and used techniques block in certain areas. After blending, the indigosol color surface is diluted with $\mathrm{HCl}$ liquid that has been dissolved in cold water.

g. Step 7: dry the cloth to dry, then soak it in a bucket filled with fixanol liquid that has been dissolved in water $3 / 4$ the size of the bucket for 6 hours.

h. Step 8: trim the edges of the fabric with a wool mat and ironed and then put into plastic and collected.

3. Product The results of the stages of learning a. The framework for developing printed batik is integrated with the motifs of each region.

b. Batik motif design.

c. Design of batik stamp tools.

d. Batik pattern design.

e. Batik cloth stamp. 
4. Press The pressure faced by students during the process of making printed batik. a. number of meetings is relatively short, namely $3 \mathrm{x}$ meetings.

b. Time to make batik development framework in $1 \mathrm{x}$ meeting.

c. Consultation and guidance for 1 month.

d. The practice time to make batik in 1 day is on Sunday with the division in the first and second week.

Based on Table 1, stage 4P contains habitus as a system of practical production schemes, systems of perception, and appreciation practically related to aesthetics that allow for non-aesthetic responses within an object, different defined in terms of philosophical logic. Of all the groups that did the practice, it was found that most of them had followed the procedure of creative thinking quite well. Although in each group often faces differences of opinion. The students' habit in creating art followed by adapted learning methods and models adds to their more mature and neatly conceptualized thinking. So competence can be achieved.
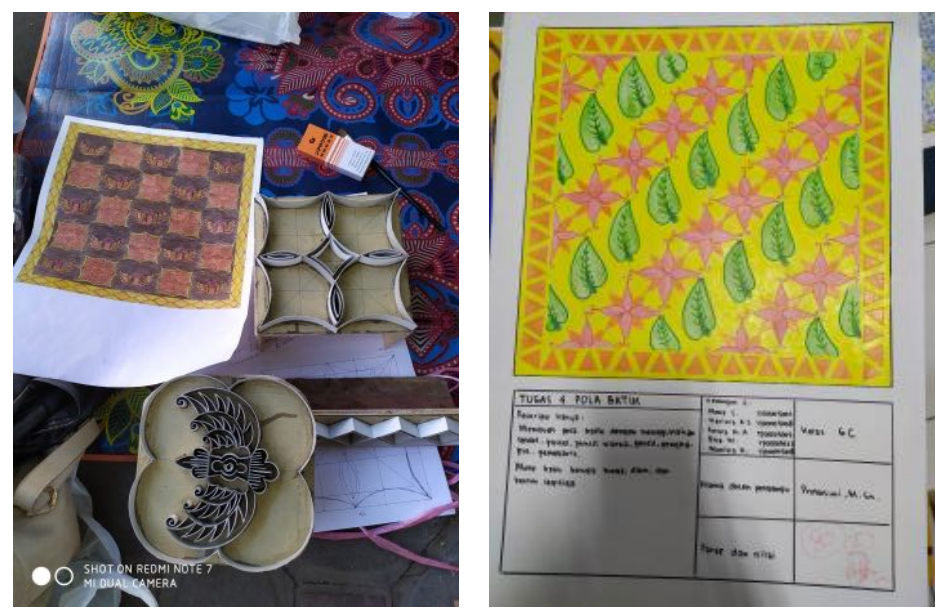

Figure 1. "Cap" Master (left), Design (right) (Photograph: Probosiwi, 2019) 
Probosiwi, Habitus Creativity of Elementary Teacher ...

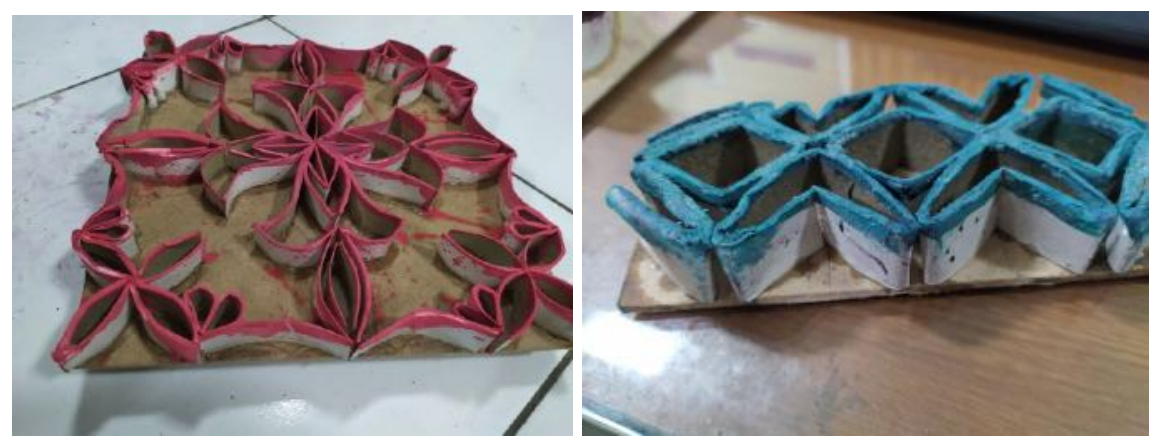

Figure 2. Detail of "Cap" Master

(Photograph: Vais Febrian, 2019)
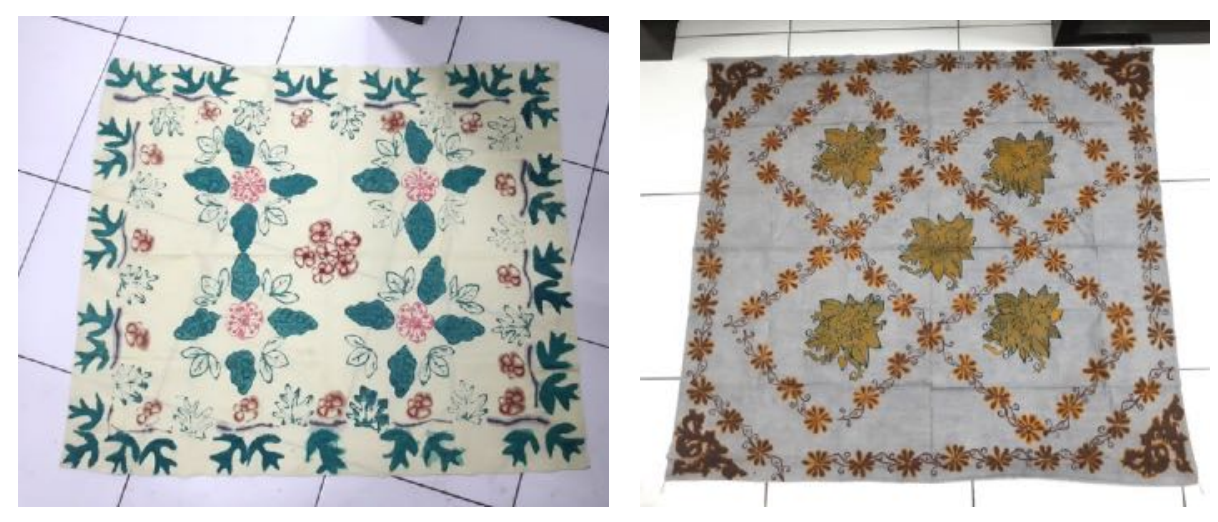

Figure 3. The Examples of "Batik Cap"

(Photograph: Vais Febrian, 2019)
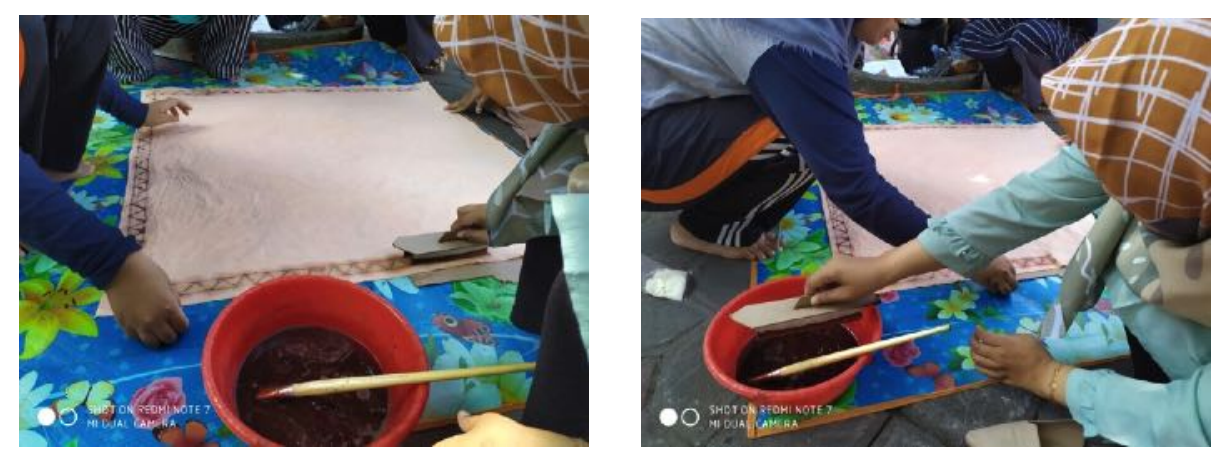

Figure 4. Stamping process with Naptol and Indigosol (Photograph: Probosiwi, 2019) 

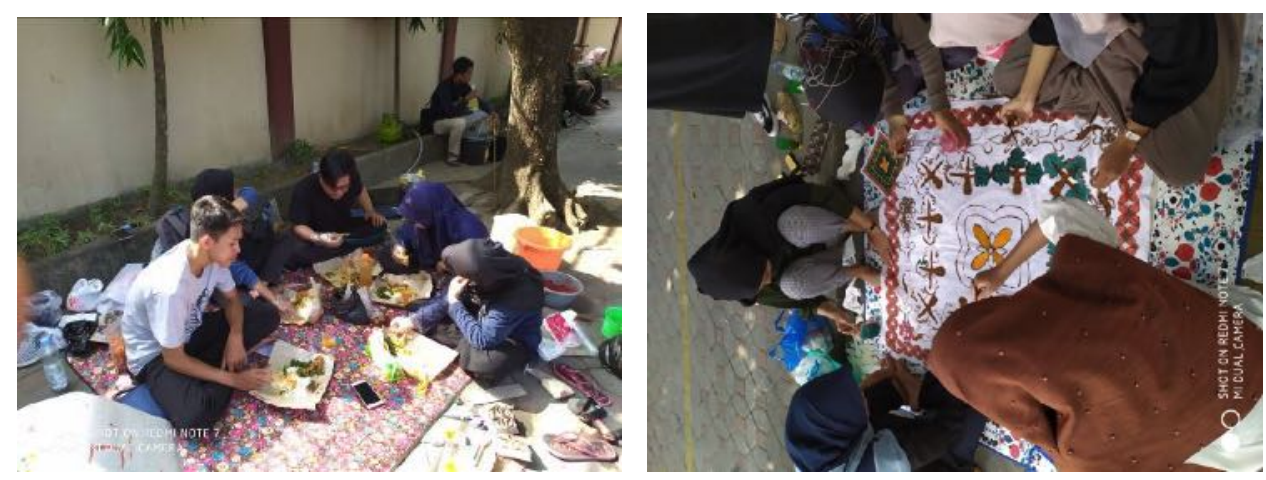

Figure 4. "Colet" processing

(Photograph: Probosiwi, 2019)

\section{CONCLUSION}

In learning art-based learning model, technical and strategic efforts are needed so that the achievement of creating art works according to the target. Stages $4 \mathrm{P}$ become one of the strategies in learning art in elementary schools that can be read sequentially to the stages of work. The results obtained can also meet the beautiful requirements as a condition of a work of art.

\section{REFERENCES}

Anugraha, Rino Andias; Sutan, Wiyono; Mufidah, Ilma. (2015). "The Design of Batik Stamp Tool Scraping Working Table Using Ergonomics Principles". Proceeding. Industrial Engineering and Service Science 2015, IESS 2015. Procedia Manufacturing 4. Published by Elsevier B.V. This is an open access article under the CC BY-NC-ND license. Page: 543-551.

Daly, Shanna R; Mosyjowsky, Erika. A; Oprea, Stephanie. L; Huang-Saad, Aileen. (2016). "College Students' Views of Creative Process Instruction Across Disciplines". Journal. Thinking Skills and Creativity. Received on $18^{\text {th }}$ of May 2015. Revision received on $22^{\text {nd }}$ of July 2016. Received on $30^{\text {th }} 2016$. Available online on $9^{\text {th }}$ of August 2016.

Grenfeel, Michael. (2008). Pierre Bourdieu Key Concepts. Edited by Michael Grenfeil. Cromwell Press: Trowbridge.

Johan, Tri Monarita, et.al. (2018). "Development of Competence-Based Art Learning Model in Primary School Students". Journal. Advances in Social Science, Education and Humanities Research, Volume $299 . \quad 5^{\text {th }}$ UPI International Conference on Technical and Vocational Education and Training (ICTVET 2018). Published by Atlantis Press. This is an open access article under the $\mathrm{CC}$ BY-NC license (http://creativecommons.org/licenses/by-nc/4.0/). 
Kaun, Linda. (2001). “Ancient Tools for Modern Times”. Magazine. GARUDA, Inflight Magazine. February 2001. Pages 20-21.

Moleong, Lexy. (2018). Metodologi Penelitian Kualitatif. Bandung: PT. Remaja Rosdakarya.

Rante, Hestiasari. (2014). "A Digital Batik Tool: Supporting Children in Understanding and Constructing Traditional Batik Patterns Within a Museum Context". Journal. International Journal of Multidisciplinary Education and Research-IJMER. Volume 1, Issue 2. Publication Date: 30 September, 2014.

Reingold, Matt. (2018). "Student Perspectives on the Relevance and Importance of Arts-Based Learning". Journal. Journal of the Canadian Association for Curriculum Studies (JCACS). Volume 16, Number 2, 2018.

Sarosa, Samiaji. (2017). Dasar-dasar Penelitian Kualitatif. Jakarta: Indeks.

Savoie, Alain. (2015). "Aesthetic Experience and Creativity in Arts Education: Ehrenzweig and the Primal Syncretistic Perception of the Child". Journal. Cambridge Journal of Education. ISSN: 0305-764X (Print) 1469-3577 (Online) Journal homepage: http://www.tandfonline.com/loi/ccje20.

Sit, Masganti, et.al. 2016. Pengembangan Kreativitas Anak Usia Dini Teori dan Praktik. Medan: Perdana Publishing.

Sovia, Iif. 2016. "Penguasaan Pengetahuan Pembuatan Batik Cap Pada Peserta Didik SMKN 14 Bandung”. Jurnal. Family Edu. Vol II No.1 April 2016. Universitas Pendidikan Indonesia Bandung.

Stavridi, Sylvia. (2015). "The Role of Interactive Visual Art Learning in Development of Young Children's Creativity". Journal. Creative Education, Vol. 6, Issue 21 (December 2015), ISSN Print: 2151-4755, ISSN Online: 2151-4771.

Supriono, Primus. (2016). Ensiklopedia The Heritage of Batik: Identitas Pemersatu Kebanggaan Bangsa. Yogyakarta: ANDI.

Sutari, Wiyono; Yekti, Yusuf Nugroho Doyo; Astuti, Murni Dwi; Sari, Yuvie Mutiara. (2015). "Analysis of Working Posture on Muscular Skeleton Disorders of Operator in Stamp Scraping in "Batik Cap" Industry". Proceeding. Industrial Engineering and Service Science 2015, IESS 2015. Procedia Manufacturing 4 (2015), Published by Elsevier B.V. This is an open access article under the CC BY-NC-ND license. Page: 133-138.

Syahputra, Ramadoni \& Soesanti, Indah. (2017). "Solar Home System Application in Batik Industry". Journal. International Journal of Applied Engineering Research ISSN 0973-4562 Vol. 12, Number 16 (2017). Page: 5995-6001 C) Research India Publications. http://www.ripublication.com 
IJCAS Vol. 6 No. 2, December 2019 | p-ISSN 2339-191X | e-ISSN 2406-9760

Widiaty; Riza, L. S.; Abdullah, A. G.; Ana. (2015). "A Preliminary Study on Augmented Reality for Learning Local Wisdom of Indonesian Batik in Vocational Schools". Proceeding. International Conference on Innovation in Engineering and Vocational Education (ICIEVE 2015). Published by Atlantis Press.

Wulandari, Ari. (2011). Batik Nusantara: Makna Filosofis, Cara Pembuatan \& Industri Batik. Yogyakarta: ANDI.

Ulger, K. (2018). "The Effect of Problem-Based Learning on the Creative Thinking and Critical Thinking Disposition of Students in Visual Arts Education". Journal. Interdisciplinary Journal of Problem-Based Learning, 12(1). https://doi.org/10.7771/1541-5015.1649. 